NBER WORKING PAPER SERIES

\title{
THE NEGATIVE INCOME TAX AND \\ THE EVOLUTION OF U.S. WELFARE POLICY
}

\author{
Robert A. Moffitt \\ Working Paper 9751 \\ http://www.nber.org/papers/w9751 \\ NATIONAL BUREAU OF ECONOMIC RESEARCH \\ 1050 Massachusetts Avenue \\ Cambridge, MA 02138 \\ June 2003
}

Robert A. Moffitt is Professor of Economics, Johns Hopkins University, Baltimore, Maryland. The author is also a Research Associate, National Bureau of Economic Research, Cambridge, Massachusetts; a Research Affiliate, Institute for Research on Poverty, University of Wisconsin, Madison, Wisconsin; and Faculty Affiliate, Joint Center on Poverty Research, Northwestern University and the University of Chicago, Evanston, Illinois. His e-mail address is moffitt@jhu.edu. An original draft of this paper was presented at the Conference to Honor Milton Friedman, University of Chicago, November 8, 2002. The paper has benefited from comments by Milton Friedman, Gary Becker, and others at that conference, comments on a preliminary version by seminar participants at the London School of Economics, and comments by Charles Brown, Timothy Taylor, and Michael Waldman of this journal. The views expressed herein are those of the authors and not necessarily those of the National Bureau of Economic Research.

(C)2003 by Robert A. Moffitt. All rights reserved. Short sections of text not to exceed two paragraphs, may be quoted without explicit permission provided that full credit including (C) notice, is given to the source. 
The Negative Income Tax and the Evolution of U.S. Welfare Policy

Robert A. Moffitt

NBER Working Paper No. 9751

June 2003

JEL No. I13

\section{ABSTRACT}

The negative income tax proposed by Milton Friedman represents one of the fundamental ideas of modern welfare policy. However, the academic literature has raised two difficulties with it, one challenging its purported work incentives and the other suggesting the possible superiority of work requirements. In addition, work requirement approaches have gained ground in actual U.S. welfare policy over the last 30 years and the number of different programs has proliferated, another development counter to the negative income tax. On the other hand, the Earned Income Tax Credit has produced a negative-income-tax-like program on a vast scale.

Robert A. Moffitt

Department of Economics

Johns Hopkins University

3400 N. Charles St.

Baltimore, MD 21218

and NBER

moffitt@jhu.edu 
The negative income tax represents one of the fundamental ideas of modern analysis of welfare programs. Its name derives from an opposition to a positive income tax, where the government claims a portion of income and where the amount paid increases as income rises. In contrast, the negative income tax sends money back to the taxpayer, like a refundable tax credit, but reduces the payment as income rises. The government provides a certain level of benefits, or reverse tax payment, even when income is zero, but then gradually withdraws those benefits as earned income rises. The withdrawal of benefits, or a "negative" income tax, reduces the marginal take-home income gained from working in the same way as does a positive income tax.

However, whereas the work incentives of positive tax programs are generally judged by a comparison of their effects relative to no tax program at all, the work incentives of a negative income tax are generally judged by a comparison of their effects relative to a welfare program with a so-called 100-percent tax rate. In that type of program, benefits are reduced by $\$ 1$ for every $\$ 1$ of additional earned income, providing no incentives to work. A negative income tax, by reducing benefits by less than a dollar for every dollar of additional earned income, arguably increases work incentives. Several decades ago, policymakers often gave little thought to the incentives created by welfare programs and consequently most welfare programs had 100 percent tax rates, so this became the benchmark for comparison, and became the program whose defects the negative income tax are intended to address.

In 1962, Milton Friedman proposed that all welfare programs be restructured with the 
negative income tax in mind, so that government support for those with low incomes would be withdrawn only at a low marginal rate. This proposal for a consistent and explicit negative income tax at a low marginal rate soon found a number of academic champions, including Lampman (1965,1968), Tobin (1966), Tobin et al. (1967), and many others. The proposal has has been a major influence both in policy circles and in the academic literature. In the policy dimension, the negative income tax proposal inspired multi-million-dollar field experiments in the United States in the 1960s and 1970s to measure its effects on labor supply, and a version of a negative income tax was proposed by President Nixon and considered by other presidents thereafter. While a negative income tax in its pure form has never passed Congress, tax rates in existing welfare programs have been sometimes altered for work incentive reasons. In the academic dimension, there is a very large literature on the negative income tax and its effect on work incentives, and the idea has filtered down to introductory economics textbooks. Indeed, the negative income tax has become the benchmark for the modern analysis of all means-tested transfer programs.

In this essay, I will review Friedman's proposal for a negative income tax and outline what he saw to be its chief advantages. I will then consider two challenges to the central ideas of the negative income tax which appear in the academic literature, one having to do with the labor supply effects of a negative income tax which run counter to its intended work incentives, and one having to do with using work requirements to induce increased labor supply instead.

In addition, I will review the history of U.S. welfare policy over the last 30 years and how it relates to the negative income tax. The idea of using financial incentives to encourage welfare recipients to work has ebbed and flowed over the years, and recently undergone another 
resurgence in policy circles, as virtually all U.S. states have lowered their welfare tax rates subsequent to being allowed to do so by 1996 federal legislation. The number of welfare programs in existence has grown dramatically, and this has had a major impact on the overall work incentives of the system as a whole, which can be thought of in negative income tax terms. That impact has sometimes been consistent, and at other times inconsistent, with the negative income tax idea. But the growth of the Earned Income Tax Credit in the 1990s has introduced a type of negative income tax on a vaster scale that Friedman ever imagined.

Milton Friedman's Negative Income Tax

Friedman originally proposed the negative income tax in his 1962 book Capitalism and Freedom, written with the assistance of Rose Friedman, in a brief chapter on the welfare system. He described how the benefit formula would work and why it would provide incentives to work by permitting welfare recipients to experience an increase in take-home income if they worked more.

The standard diagram illustrating these effects is shown in Figure 1, an income-leisure diagram. The line ADD'F illustrates how income rises with increased hours of work (at the rate determined by the hourly wage rate). The flat segment $\mathrm{CD}$ denotes the constraint created by a welfare program with a 100 percent negative income tax rate, where the government guarantees the level of income at $\mathrm{C}$ even with zero hours worked, but then withdraws $\$ 1$ of benefits for every $\$ 1$ earned. A utility maximizing individual facing this welfare program will either choose point $\mathrm{C}$, with no hours worked, or some point on the upward-sloping segment of the budget line 
DD'F. The segment CD' denotes the constraint created by an negative income tax with a lower tax rate, where the government guarantees the level of income at $\mathrm{C}$ with zero hours worked, but then withdraws less than $\$ 1$ of benefits for every $\$ 1$ earned. With the negative income tax at a rate lower than 100 percent, increased labor supply will occur as some of those who maximized utility at $\mathrm{C}$ will maximize it at some choice with positive hours worked. Their movement is shown by the arrow from point $\mathrm{C}$ to point $\mathrm{E}$. The formula for benefits received by the individual is $\mathrm{B}=\mathrm{G}-\mathrm{t} \mathrm{Y}$, where $\mathrm{G}$ is the guarantee, $\mathrm{t}$ is the tax rate, and $\mathrm{Y}$ is recipient earned (or nontransfer) income. A version of this diagram has entered undergraduate principles textbooks as a vivid example of how to use price theory and budget lines to analyze important public policy issues.

Although Friedman did not give a numerical example in his 1962 essay, he later suggested that a family of four be given a guarantee of $\$ 3600$ per year (1978 dollars) and a negative income tax rate of 50 percent. Thus the vertical distance AC in Figure 1 would be $\$ 3600$ and each dollar of earnings would reduce the benefit by 50 cents. When income reached $\$ 7200$, the benefit would reach zero, corresponding to point D' in the figure.

Along with improved work incentives, Friedman (1962) noted five other advantages to the negative income tax. First, the negative income tax has the advantage of providing support to poor families solely on the basis of their income, and not on the basis of some other characteristic purported to correspond to need like old age, or whether the person is a farmer. Second, the negative income tax provides cash, which is the best form of support from the point of view of the recipient. Third, a negative income tax could be substituted for the then-existing "rag bag" of multiple programs set up to affect income distribution.. Fourth, a negative income 
tax could cost less than the existing system by saving administrative costs and by concentrating benefits more easily on the poor. Indeed, Friedman also proposed folding the negative income tax into the tax system, integrating its rate with the positive income tax rate, and administering it through the Internal Revenue Service. In Friedman's view, this integration of the positive and negative income tax would reduce invidious distinctions between the poor and nonpoor or, in modern parlance, reduce stigma. Fifth, Friedman saw as an additional advantage that the negative income tax does not distort market prices that minimum wages, tariffs, and farm supports do, which are often also argued on the basis of distributional considerations. All of these advantages have figured in subsequent U.S. policy debates and hence will be discussed further below when that policy is reviewed, as well as the central work incentive argument.

In 1969, Friedman spelled out some additional details of his views on the negative income tax in testimony before Congress. The subject at the time was a version of the negative income tax proposed by President Nixon called the Family Assistance Plan. Friedman's main objection was that in Nixon's approach, the negative income tax would be layered on top of other programs then in existence, instead of replacing all those programs. A negative income tax on top of the other programs would result in cumulative marginal tax rates that could be very high if a family received benefits from multiple programs, and the administrative simplicity of the negative income tax would be lost. In his testimony, Friedman (1969) also reiterated some of the advantages of an negative income tax: equal treatment of equals, benefits based solely on the objective criterion of income, and the separation of financial assistance from other social services. In addition, Friedman noted that the Family Assistance Plan legislation proposed that job training and other services be provided only to those on welfare, and warned 
that this might draw individuals onto welfare. This issue has repeatedly surfaced in the $1980 \mathrm{~s}$ and 1990s (Moffitt, 1992, 2003b).

In the 1980 book Free to Choose, Milton and Rose Friedman provided their most detailed critique of the existing welfare system in the United States, as well as that in Britain and other countries, along with a more detailed discussion of the negative income tax. The case for the negative income tax as opposed to the existing welfare system is that it will improve work incentives, reduce the bureaucracy for administration, eliminate the multiplicity of overlapping programs, and target benefits on the poor and not the middle class. ${ }^{1}$ They acknowledge that some families might have special needs that would not be met by the cash program, but argue that such special needs could be supported by private charity.

In an important new discussion, Friedman and Friedman (1980) discuss the tradeoff between work incentives and cost, which had become a common subject in the 1960s and 1970s (for example, Aaron, 1973). The problem is that if the guaranteed level of income for those who do not work at all is set relatively high in order to provide an adequate income to those with no other funds, and if the rate of the negative income tax at which benefits are withdrawn is relatively low in order to provide reasonable work incentives, the overall cost of the program may be unacceptably high. Friedman and Friedman proposed to address this problem by setting the guaranteed level of income relatively lower than in the existing system on the argument that the existing system, with its multiple programs, provides too much support income for those who do not work at all. They note the political problem created by this proposal, because it

1 They also note the incentives for interstate migration in the existing system, but did not address this issue further. This argument is usually made in support of a system with federallyset, nationwide benefit levels rather than allowing states to set their own. 
would make some families worse off, but also note that it makes a low rate for the negative income tax and stronger work incentives possible.

Federalism and Family Structure

Two issues that have played an important role in the academic literature and policy developments surrounding a negative income tax but which were not addressed by Friedman are issues of federalism and family structure.

A long-standing criticism of the existing cash welfare system that first arose in the 1960 s is the large variation in benefit levels across states. In 1998, California paid $\$ 673$ per month to a family of four with no other income while Mississippi paid \$144. To some of its proponents, a negative income tax meant also that the program would be federalized and a national benefit level would be set, though perhaps with cost of living adjustments. An alternative proposal was merely to set a minimum benefit, which would ease the transition problem by not requiring high benefit states to lower their benefits if federalism were introduced. This issue played an important political role because it meant, in practical terms, that total expenditures would increase greatly because the federal benefit level would be set far above that in many of the states. This was a source of political support for a negative income tax from liberals, who preferred expenditure increases, whereas Friedman preferred that expenditure be held fixed or reduced.

The academic literature has debated the relative merits of a nationally uniform benefit level versus a locally-determined one. In the 1960s, most public finance economists argued that 
the utility of the poor entered the utility function of all taxpayers in the nation equally, justifying a national benefit. But Pauly (1973) argued that if local taxpayers care much more about their own poor, redistribution could be more efficient at the local than at the national level. Others then argued that even if this were true, cross-state migration would create externalities that would make such a system inefficient (Brown and Oates, 1987; see also Brueckner, 2000 and Wheaton, 2000). Indeed, the literature on Tiebout models of sorting of the population by preferences for a public good often have difficulty even establishing an equilibrium in the presence of local redistribution, given the migration problem. For better or worse, however, policy has moved strongly in a local public good direction as states have been given increasing authority over benefit levels and eligibility requirements, and this issue is no longer discussed in policy circles.

The proponents of a negative income tax also argued that it should be universal and extended to all persons based on income and family size, but not restricted to single mother families or even to families at all--poor individuals without children should be eligible. While Friedman argued that a negative income tax should be based purely on income and not other characteristics, he did not directly address incentives to change family structure. Offering benefits only to single mother families creates an incentive to not marry, and offering benefits only to those with children additionally creates an incentive to have children outside of marriage. Once again, extending benefits to other family types without compensating benefit reductions or other savings would result in a significant increase in expenditure, and was therefore often a source of support by liberals.

The theoretical literature on models of family structure generally supports the common- 
sense proposition that offering benefits only to one family type will increase the number of families of that type. One exception is if welfare is viewed as social insurance and the event of a divorce (for example) is viewed as a stroke of bad luck which should be insured against. In such a model, provision of insurance should actually encourage the risky endeavor, which in this case is getting married. However, the moral hazard problem in such insurance is the obvious problem with the model.

It should also be noted that even a universal negative income tax would not eliminate all incentives to not marry, at least if the tax unit is the family rather than the individual. Two individuals with incomes Y1 and Y2 who are both eligible for benefits on their own, but for whom combined, married income $\mathrm{Y} 1+\mathrm{Y} 2$ puts them above the income eligibility point, have a disincentive to marry relative to the situation with no program. This is a familiar result from the literature on the marriage penalty in the income tax (Alm et al., 1999), which has demonstrated that it is not possible to have a tax program that is simultaneously progressive, which bases taxes or benefits on family income and not individual income, and which is neutral with respect to family structure. Means-tested programs are progressive by definition--that is, benefits are available only to those with low income--and basing benefits on individuals would violate vertical equity considerations and create difficulties for the treatment of children.

Are the Labor Supply Effects Ambiguous?

Two issues have been raised in the academic literature which challenge central tenets of 
the negative income tax. This section suggests the possibility that the labor supply effects of a negative income tax are ambiguous; the next section discusses the role of work requirements.

The first question concerns whether labor supply would be increased or decreased by a reduction in the welfare tax rate. The problem is illustrated in Figure 2, where the negative income tax line is now dotted and where the arrows show possible labor supply responses. At least some of the individuals who decided in the face of a 100 percent negative income tax rate to work zero hours, at choice $\mathrm{C}$, will now increase labor supply, as denoted by arrow 1 .

However, other individuals initially chose to work positive hours and not to receive benefits and were located on the upward-sloping portion of the budget set, DD'F. When the negative income tax rate is reduced, it becomes possible for these individuals to choose a combination of higher income and less work, as shown by arrow 2 , or a combination of much more leisure and lower income, as shown by arrow 3. The lowering of the negative income tax rate tends to draw onto welfare families that had not been on the rolls previously, reducing their labor supply. The change in average labor supply of the population is therefore ambiguous in sign.

This ambiguity has nothing to do income and substitution effects pushing work effort in different directions; it would remain even if substitution effects always dominated income effects in labor supply functions. In addition, this problem is not directly linked to cost. If the movements shown by arrows 2 and 3 are relatively common, compared to the movement shown by arrow 1 , it is possible that both cost would increase and labor supply would fall as a result of a lower rate for the negative income tax. Thus the idea that the negative income tax poses a tradeoff between work incentives and cost is not necessarily correct.

Some empirical evidence on the issue is provided in Table 1. The table presents 
simulations of the effects of negative income tax programs on weekly hours of work, based on the population of single mothers, the main eligibility group for cash welfare. The columns of the table show a range of different rates for the negative income tax. The rows show different rates of guaranteed income, where $\mathrm{G}=1$ means that the guaranteed income is set at the poverty line. A range of estimated elasticities taken from the labor supply literature was applied to a representative sample of the population.

Each cell in the table shows the labor supply reduction resulting from an negative income tax of a particular guaranteed income level and negative income tax rate relative to no welfare program at all. All entries are negative, reflecting that fact that the negative income tax, like all means-tested transfer programs, reduces labor supply. The table shows that hours of work rise from tax rate reductions in most cases, but the rise in hours worked as the negative income tax rate falls are sometimes small, and sometimes the effect is even reversed. A rise in hours worked is more likely when elasticities are low than when they are high (e.g., going from -.81 to -.49 versus going from -2.06 to -2.22 , for $\mathrm{G}=.50$ and going from $\mathrm{t}=1.00$ to $\mathrm{t}=.75$ ), which is a reflection of the fact that high elasticities mean a more substantial negative labor supply response among those in the upper reaches of the constraint who become newly eligible.

The variability implied by these simulation results is confirmed by data from the negative income tax experiments of the 1970s. For example, one experiment conducted in Seattle and Denver in the 1970s considered the changes in labor supply at negative income tax rates of 70 and 50 percent (SRI International, 1983, Table 3.9). The study was able to examine the effects of this change on husbands, wives, and single mothers. For husbands and wives, a lower negative income tax rate reduced the quantity of labor supplied - in effect drawing more 
of them into the welfare system. For single mothers, a reduction in the rate of the negative income tax usually increased labor supply but sometimes decreased it, depending on the level of guaranteed income. The difference in responses of the two groups is partly a result of their different incomes. Married men and women have higher incomes than single mothers, and consequently are more likely to be around points D and D' in Figure 2, whereas single mothers are more likely to be located around point C. But there is a nontrivial fraction of single mothers in the upper regions as well, leading to the variability in their responses to the tax rate reduction.

The policy lesson is that an negative income tax may increase labor supply for some groups and not others; at some levels of guaranteed income levels and implicit tax rates and not others; and for some income distributions and not others, depending on the relative numbers of families at different points along the budget constraint. As a result, the effects of the negative income tax on labor supply may differ across places, across groups, and across time. This finding clearly creates difficulties in making the case for an negative income tax.

This ambiguity of the negative income tax on work effort is shared by other reforms. For example, some welfare programs have so-called "notches," where benefits are suddenly reduced to zero for an extra hour of work and where the tax rate is effectively in excess of 100 percent. For example, many of the cash programs in the U.S. such as the Temporary Assistance to Needy Families program have maximum income limits, beyond which eligibility is lost, regardless of whether the benefit formula comes out showing that a positive benefit should be paid. Notches appear to cause severe work disincentives because an individual will never work just beyond the notch. But any method by which the notch is removed will create 
some new work disincentives as well. For example, smoothing over a notch by permitting a gradually declining benefit instead of a sharply reduced one will extend benefits up the constraint and once again bring new individuals onto welfare whose labor supply will be reduced (Moffitt, 2002, provides a graphical illustration).

The common element in these two examples which creates the ambiguity is that the programmatic reform in question increases the marginal tax rate in some regions and decreases it in others. For example, the reduction in the negative income tax rate shown in Figure 2 decreases marginal tax rates for those initially at $\mathrm{C}$ but increases them for individuals initially in the range DD', thus increasing the slope of the budget constraint for the first group and decreasing that slope for the second group. Likewise, the elimination of a notch reduces marginal tax rates for those initially at the notch, but increases them for individuals who were initially working above the notch.

Friedman proposed that $\mathrm{G}$ be lowered at the same time as $\mathrm{t}$ to address this problem, as noted previously. Figure 3 shows that $\mathrm{G}$ can be lowered by just enough to keep the eligibility point--D in the figure--unchanged. The reduction in the negative income tax rate in this case shifts the segment $\mathrm{CD}$ to C'D, and individuals will move from E to E' (and some will jump up to segment DF). It is unambiguous that labor supply will increase in this case, for the extension of the budget constraint upward to the right has been eliminated.

But this example is misleading because expenditure on the program has been reduced. Indeed, in the limit, this approach would lead to the elimination of the program altogether, which will maximize labor supply, to be sure. The proper comparison is instead between two programs with equal expenditure. Then the question is whether any manipulation of the budget 
constraint can unambiguously increase labor supply, holding expenditure fixed. The answer is no, for if benefits are decreased in one region and increased in another, those changes will have opposite effects on labor supply in those two regions.

A negative income tax with a lower rate might be preferred by society even if its average labor supply effects are zero or negative. For example, if society views it as more important to encourage most people to work at least some quantity of hours, but is less worried if a larger proportion of the near-poor reduce their hours, then a negative income tax might be a desirable policy even if it led to an overall reduction in the quantity of labor supplied.

Alternatively, there may be social value in redistributing income to those who are working but still poor, for example, even if their labor supply is decreased. The implication is that the desirability of any welfare reform, along with the choice of the guaranteed income level and the negative income tax rate, requires both knowledge of the distribution of the population and its elasticity of labor supply, along with a particular social welfare function. Reforms cannot be picked solely on the basis of their labor supply effects; other considerations must come into play.

The optimal tax literature is the area where formal models of this decision have been constructed. The most well known is that of Mirrlees (1971), who presents a model of optimal nonlinear income taxation in which a lump sum tax, possibly negative, is combined with a marginal tax rate to maximize a social welfare function. A negative lump-sum tax functions like a guaranteed level of income. Mirrlees assumed a utilitarian objective function, which simply sums over all utilities, and assumed that marginal utilities decline with income, implying that there are implicit social welfare weights which are greater for those who are low income. 
The model thus implicitly assigns different weights to those along segments CD, DD', and D'F in Figure 2, for example. Mirrlees showed that redistribution to the poor improves social welfare for this reason, but this benefit must be balanced against costs arising from work disincentives and consequent reductions in output. He shows that a negative income tax is the optimal result, and that optimal tax rates at the bottom are far less than 100 percent (in fact, closer to zero), implying that the utility gains at the bottom end and lower middle portions of the income distribution from reducing the negative income tax rate are greater than the utility losses required at higher incomes given that the societal budget constraint must be met.

Fortin et al. (1993) report results of simulations using a different social welfare function and focusing more directly on the tradeoff between alternative guarantees and negative income tax rates discussed here. A class of social welfare functions based on inequality indices proposed by Atkinson (1970) was used, which contains a single parameter which can be varied to increase or decrease the relative social desirability of equality of incomes (actually, equality of utility levels, for leisure is included in the utility function). For medium levels of equality preference, optimal tax rates were in the range of .50 to .55 , quite close to Friedman's suggested tax rate, and optimal guarantees were about 66 percent of the poverty line for a family of four, which would be $\$ 11,617$ in 2000 dollars. As the preference for equality rises, the optimal tax rate also rises because, holding expenditure constant, this allows a higher level of guaranteed income which benefits those at the very bottom. Although these models should not be taken as conclusive, they do suggest that a negative income tax can be a welfaremaximizing decision for society, even when the labor supply disincentives for near-poor families are taken into account - as they are in models like these. 
Work Requirements and Categorical Transfer Systems

A work requirement system divides the population into those who "can" work and those who "cannot" work. The "employables" are denied any payment if they do not work and are provided with supplemental benefits only if they work some minimum number of hours. The "nonemployables" are given some guaranteed level of income, which may phase out at a low negative income tax rate on the presumption that they might be able to work some small amount.

Work requirements are fundamentally at odds with the idea of a Friedman-style negative income tax. With such a tax, nonworkers are not queried about the reason for their lack of work, and recipients are judged only by their income, not any other characteristic like whether they are by some criterion "employable" or "unemployable." Work requirements are also at odds with the idea of minimal government emphasized by Friedman, for they require an increase in the welfare bureaucracy to administer them and to categorize people.

Other economists have criticized work requirements on three additional (for example, Barth and Greenberg, 1971; Browning, 1975; Lurie, 1975). First, it is argued that that the government cannot adequately distinguish between those who can and cannot work, and that, in any case, there is a continuum of abilities which has no clean dividing point. Relatedly, economists believe that any adult with a severe disability can work at an appropriate wage and in an appropriately supportive work environment. A second argument is that work requirements introduce unwarranted and potentially abused discretion into the system, as different bureaucrats make different judgements about who is able to work and who is not. A 
third concern is that any system that classifies individuals and provides them with differential benefits creates an incentive for those individuals to attempt to change their characteristics so as to change the box into which they are thrown.

However, the academic literature has also provided several models in which work requirements can be seen to be advantageous. Akerlof (1978) noted that the truly needy--those with low job skills who have extreme difficulty in becoming employed--can be partly identified by some measurable, observable characteristic, which he called "tagging" the poor. For example, some combination of indications of poor health, low levels of education, and spotty employment histories might be indicators of low job skills. If the government moves from a negative income tax in which all those with income are paid benefits regardless of their characteristics to a tagged system in which only the subset who have the particular set of characteristics indicating that they are needy are paid benefits, then money can be saved and higher benefits could be paid to the tagged individuals without changing total expenditure. Akerlof partly had family structure in mind as a characteristic, for the U.S. welfare system is heavily concentrated on families with a single parent, which can also be taken as an observable indicator of need. The key parameter in the Akerlof model is the fraction of the truly needy who can be identified as such--in order words, the accuracy of the screening mechanism. If this parameter is sufficiently large, then the social welfare gains from giving higher benefits to the tagged needy can outweigh the losses arising from the denial of benefits to those who are truly needy but who do not possess the correct characteristics and hence go untagged. Akerlof addressed the problem of incentives to change categories as well, noting that there is a cost and benefit to changing categories to the individual and that even if this calculation is added to the 
optimization problem, a tagging system could still be optimal if few enough individuals change categories relative to the benefits of tagging.

Parsons (1996) showed that if there is "two-sided" error--that is, some of the tagged individuals were not truly needy, as well as some of the untagged individuals being truly needy-then, provided the error rate does not exceed certain levels, the optimal program would provide benefits to both groups, although greater benefits would be given to the tagged group. A lower marginal tax rate would be provided to the tagged group as well. A separate negative income tax would be given to each of the two groups.

An alternative but related argument for work requirements is that they can be used as a screening device to deter entry onto welfare by the more able. Besley and Coate $(1992,1995)$ present a model along these lines that uses as a social welfare criterion that incomes should be raised to some minimal level. In their most comprehensive model, a combination of a guaranteed income and a work requirement is provided to those at the bottom of the income distribution. This program begins with a 100 percent tax rate - that is, all money must first be earned through the work requirement - followed by an negative income tax-like program for those higher in the income distribution, with a less-than-100-percent tax rate. In earlier work, Nichols and Zeckhauser (1982) made a similar point by arguing that the imposition of "ordeals" on welfare recipients, of which work requirements were one example but onerous application procedures and participation requirements are others, could serve to deter entry. While the truly needy would be made initially worse off by these mechanisms, the gains in higher transfers--because there would cost savings arising from lower entry rates by the more able-could outweigh those losses. 
What these models have in common is that there is some unobservable ability upon which the government would prefer to base transfers in a first-best world but cannot, so the second-best solution involves either imperfect tagging or imposing costs on potential welfare recipients. From this perspective, a Friedman-style negative income tax could end up as thirdbest relative to a second-best work requirement program.

The empirical implications of the models in the workfare literature have not been examined in any detail. Exactly how much error is made in categorizing individuals, for example, has not been determined in actual applications. In the Akerlof (1978) model, some truly needy families are not "tagged" and hence are made worse off by a categorical system; in his model, it is clearly critical whether most of those who are "truly needy" are actually identifiable as such, and how easy it is for families to change categories. The Besley and Coate $(1992,1995)$ model has the danger that making the program ungenerous, so as to deter entry, might simultaneously penalize the truly needy who are intended to be its chief beneficiaries. ${ }^{2}$

Nevertheless, these models establish a prima facie case to justify both the existence of work requirements and for categorical transfer systems that can dominate the negative income tax in social welfare terms.

Policy Developments in the U.S. Welfare System

${ }^{2}$ Besley and Coate $(1992,1995)$ note the possibility of this tradeoff. In their preferred model, they assume that all truly needy individuals can work and would use the benefit to supplement their earnings and hence would be no worse off. But they acknowledge and emphasize the importance of this assumption. 
Policy development in the area of welfare systems in the U.S. has taken several directions over the last 30 years. Some of these are consistent with a Friedman-style negative income tax and some are inconsistent with it. The three most important trends concern the welfare tax rates, work requirements, and multiple programs.

\section{Welfare Tax Rates}

A Friedman-style negative income tax suggests that the rate at which benefits are withdrawn as income is earned should be kept relatively low. On the issue of whether welfare tax rates have actually been kept low, the policy record is rather mixed. The negative income tax rate in the main cash transfer program, Aid to Families with Dependent Children (AFDC), was 100 percent from the inception of the program in 1935 through 1967, when it was lowered to 67 percent. The tax rate was increased back to 100 percent in 1981, on the argument of the Reagan administration that concentrating benefits on the worst-off families was more cost effective and also that lower tax rates bring more families onto the rolls and reduce their work effort--precisely the theoretical point discussed above. Clearly, neither 100 or 67 percent was a low tax rate, particularly when the tax rates of other programs are added on top of it. ${ }^{3}$

However, federal welfare reform legislation in 1996 replaced Aid to Families with Dependent Children with a new program, Temporary Assistance for Needy Families. This reform had a number of components, but one change was to free up states to withdraw welfare

${ }^{3}$ States allow deductions for work-related expenses, making the 'effective' tax rate lower than 67 or 100 percent. But if those deductions are "real," meaning that they accurately reflect true expenses, then the true tax rate is still 67 or 100 percent. Some states no doubt were overly generous, however, leading to lower tax rates. 
benefits at the rate they choose as earned income increases. Since 1996, the majority of states have lowered their implied negative tax rates on cash welfare payments significantly, with 50 percent being the most common tax rate and with a scattering of rates in the $50-75$ percent range (Gallagher, 1998, Table VI.2). A few states still have rates at 100 percent and a few have rates below 50 percent, even as low as zero (in which case eligibility is terminated at a notch, when income reaches a specified maximum). Work levels among welfare recipients in the post-1996 period have risen dramatically, for more than 30 percent of recipients now work compared to 5 percent or less in pre-reform periods. Whether this change is solely the result of the reduced tax rates is an important question, for work requirements have also been introduced (as discussed below) and the economy has improved over the period.

However, the most important policy development germane to welfare tax rates has taken place outside the traditional cash welfare system, and is represented by the rise of an earnings subsidy called the Earned Income Tax Credit. This credit provides a subsidy to earnings up to some maximum point, after which it is phased out. The specific rates and income levels at which the credit is phased in and phased out are different according to the number of children in the family (Hotz and Scholz, 2003, Table 1). But in 2001, for example, taxpayers with more than one qualifying child were eligible for a tax credit of 40 percent of income earned up to $\$ 10,020$, at which point the maximum value of the credit was $\$ 4,008$. The amount of the credit received was not reduced as income increased from $\$ 10,020$ to $\$ 13,090$. However, for income above $\$ 13,090$ the credit was reduced at a marginal rate of 21.06 percent - which implied that the credit phased out completely at an income level of $\$ 32,121$.

Figure 4 shows the budget constraint created by a earnings subsidy program like the 
Earned Income Tax Credit. The program creates the budget constraint ABCDE. Once again, the effect on average labor supply is ambiguous although work effort at the lower end is likely to be increased. The most plausible scenario is that an earnings subsidy program will increase labor supply for those in the subsidy region where it increases the marginal returns to work (assuming that substitution effects dominate income effects), as shown by arrows 1 and 2 . However, an earnings subsidy is likely to decrease labor supply for those in the flat and phaseout regions where it flattens the budget curve, as shown by arrows 3,4 , and 5 .

Earnings subsidies are not intended to replace welfare programs because such subsidies do not provide any support to needy families who have no other income. In fact, in and of themselves, earnings subsidies are regressive in their low ranges, providing fewer benefits to more needy families rather than greater benefits. Actual policy provides both programs, as indicated in Figure 5, which combines a basic negative income tax AFG, with a guaranteed level of income and a rate at which that support is withdrawn as income is earned, with the earnings subsidy program ABCDE. The total tax rate faced by an individual is the sum of the tax rates in the two programs. ${ }^{4}$ In low ranges of earnings, an individual receiving benefits from both programs would have a quite low tax rate. For example, an earnings subsidy rate of 40 percent would cancel out most of a negative income tax rate equal to 50 percent, leaving only a 10 percent total tax rate. As the earnings subsidy rate changes to zero in region $\mathrm{BC}$, the total tax rate would rise to 50 percent, and if the EITC phaseout region CD were entered before the welfare program ended, the total tax rate would rise to 71 percent (50 plus 21 percent for the

4 This assumes that the welfare program does not include the EITC in income when computing benefits. In fact, few states do so. 
phaseout). But after leaving the welfare program(i.e., beyond point $\mathrm{G}$ ), the negative income tax rate would no longer be faced at all, and either the zero region or the phaseout region of the EITC would be faced alone, which gives a total tax rate of 0 or 21 percent, less than that of the welfare program. Thus the total marginal tax rate starts low, then rises and then falls.

However, the average marginal tax rate, measured by the average benefit reduction from going from point $\mathrm{F}$ to point $\mathrm{D}$ in Figure 5, is lower than 50 percent, which is the marginal tax rate on segment FG alone. That is, the EITC lowers the average marginal tax rate and raises the eligibility point for benefits from point $G$ to point $D$.

The Earned Income Tax Credit represents an extraordinary expansion in the cash welfare system that has extended benefits far up the income distribution. The earned income tax credit provides income for those earning up to $\$ 32,000$ in 2001 . In comparison, cash welfare programs, even after the reduction in their average negative income tax rates and consequent increases in eligibility levels up to higher income points, phase out their assistance at the range $\$ 6,000$ to $\$ 12,000$ for the majority of states (Gallagher, 1998, Table III.3). Expenditures on the earned income tax credit passed up expenditures on cash welfare in 1996, and the gap has widened since that time (\$26 billion for the earned income tax credit and \$14 for the Temporary Assistance for Needy Families program in 2000; see Moffitt, 2003a, Table 1). In 2000, only six million individuals received cash welfare payment, and 55 million received support through the Earned Income Tax Credit program (Moffitt, 2003a, Table 3).

Thus, with a combination of the earned income tax credit and the state welfare reforms since 1996, the United States has an effective negative income tax on a scale far beyond that imagined by Friedman. The level of guaranteed support has been kept relatively low--guarantee 
levels in state cash transfer programs are far below the poverty line, often only half of it--but the implicit, average tax rate is also extremely low, leading to correspondingly high expenditures and eligibility for benefits which extends high up into the income distribution. One major question is whether average labor supply has been increased or decreased as a result of this super-negative income tax. One study found that the overall effect on labor supply of women is positive, but that while the labor supply of single mothers has been increased, the labor supply of secondary workers, primarily married women, has been reduced (Hotz and Scholz, 2003). This pattern fits with the earlier discussion. The positive effect for labor supply of single women is a reflection of the concentration of that population group in the lower income ranges, where the earning subsidy is especially powerful. The negative effect for secondary workers is a reflection of the heavy representation of that group at the levels of income where the earned income credit is being phased out. As before, the social desirability of the program cannot be judged on the basis of labor supply effects alone, which are typically ambiguous in sign overall, but requires a social welfare function which weights the gains for each group.

Work Requirements

Work requirements have been a growing feature of U.S. welfare policy starting in the 1970s, and especially following the welfare reform act of 1996, they have become a central element of cash welfare programs like Temporary Assistance for Needy Families.

The seeds of the work-requirement philosophy appeared in the defeat of the Nixon administration's negative income tax plan in 1969. According to an authoritative account of the Congressional debate (Moynihan, 1973, Chapter 7), the negative income tax foundered 
partly because members of the Senate came to understand the work incentive issue and became aware that the existing welfare program had work disincentives, which was judged to be politically unacceptable. A program which merely reduced those disincentives became of little interest; politicians were unwilling to consider the tradeoffs between the guaranteed level of support and the negative income tax rate at which that support is phased out. This unwillingness represents a fundamental rejection of the negative income tax philosophy.

After the failure of the Nixon administration's proposed negative income tax, work requirements for welfare recipients were proposed by the Carter administration, albeit coupled with a major public service employment program. The Reagan administration encouraged states to experiment with mandatory work programs in the 1980s, and states did so but kept them on a small scale. In the early 1990s, states began imposing mandatory work requirement programs on larger fractions of their caseloads. Under the 1996 welfare reform, the federal government required that states enroll minimum fractions of their caseloads in work or in a work-like activity. The legislation specified that work-like activities could include job search, but not general-purpose education and training. It also specified a work requirement of 20 hours per week, rising to 30 per week. The work requirements adopted by the states thereafter greatly reduced the number of exemptions that had previously been allowed, as well as imposing much stronger sanctions for noncompliance like reductions in benefits or even full termination from the welfare rolls. The legislation provided for additional funds for child care, but eliminated a rule in the pre-1996 program stipulating that recipients were not obligated to work if the government could not provide them with child care.

The critical issue of who is deemed as employable and therefore subject to the work 
requirements remains unclear. Exemptions from the work requirements vary greatly from state to state. Discretion, the predictable accompaniment of work requirements, appears from anecdotal evidence to be widespread (Diller, 2000, Lurie, 2001). Caseworkers make judgements about whether individual recipients have made sufficient effort to find a job, for example. No evidence is available on the overall accuracy of the employability distinctions.

Other consequences of this shift toward work requirements are largely as predicted. Expenditures per welfare recipient have increased, because the government is more heavily involved in regulating the individual lives of welfare recipients than at any point in the history of the program, with a correspondingly significant increase in administrative costs. The work requirements have been one major reason that the welfare caseload has fallen by over 50 percent in recent years; in turn, part of the reason for this decline is that work requirements screen out some potential recipients who have less need for such support, as Besley and Coate $(1992,1995)$ argued. On the other hand, the prediction that work requirements allow an increase in expenditure on those in greatest need also has support. States have used the monies freed up by the reduced welfare caseloads to create new programs to address special problems for the remaining recipients, such as special job search programs, substance abuse treatment programs, and the like.

This increase in work requirements also sheds a somewhat different light on the supernegative income tax created by the combination of the earnings subsidy and cash welfare, discussed above. The combined program of guaranteed income and an earnings subsidy shown in Figure 5 is available only to those who are judged unable to work, for only that group is guaranteed some income whether they work or not. For those judged capable of working, the 
more relevant program at low hours of work is the earnings subsidy alone - since no income support is provided without achieving some minimal hours of work like 20 or 30 per week.

\section{Multiple Welfare Programs}

A Friedman-style negative income tax would replace all existing welfare programs. In this regard, U.S. policy has again moved in the diametrically opposite direction.

Table 2 shows the growth of expenditures on means-tested transfer programs in the U.S. from 1968 to 2000. Total per capita expenditures on all programs combined have risen over time, but the composition has clearly shifted toward in-kind programs and special-purpose programs for different populations. The largest growth has occurred in the medical programs, primarily Medicaid, which has experienced a major increase. Indeed, means-tested expenditures for medical care in 2000 are greater than the sum of all other means-tested expenditures. The growth in means-tested expenditures on medical care was partly the result of increasing expenditures on the aged and disabled, but also partly the result of the extension of eligibility for benefits to additional groups in the low income population (Gruber, 2003). Cash transfers also grew, primarily as a result of the Earned Income Tax Credit and the Supplemental Security Income program for the disabled. Also experiencing growth were programs supporting expenditures on food, housing, education, training, social services (which includes child care), and energy.

It is useful to separate the different issues raised by this increasing categorization. The administrative cost of such a system clearly exceeds that of a negative income tax. Moreover, categorization into a number of programs increases the burden of the system on the recipients 
themselves, as they must travel to different offices to establish eligibility and to comply with each program's requirements. The participation rates of eligibles tend to decline when programs multiply. For example, when recipients leave the cash welfare program, their participation rates in in-kind programs drop because of the difficulty in visiting different welfare offices (Garrett and Holahan, 2000; Zedlewski and Brauner, 1999). Both higher administrative and individual costs might be ameliorated with one-stop welfare offices, which establish eligibility for multiple programs and dispense benefits in one location.

A different issue is that the withdrawal of benefits from a number of individual programs may potentially lead to high cumulative negative income tax rates. Given the ambiguity of the sign of the effect of welfare tax rates on labor supply noted above, it is not clear how serious this problem is in the aggregate. However, it is certainly injurious to the more narrow goal of increasing labor supply among the poorest individuals. Cumulative tax rates in the U.S. from participation in multiple programs are nevertheless not as high as might be expected. Because of the recent reductions in welfare tax rates and the presence of the earned income tax credit, the implicit negative income tax rates from the cumulation of current welfare programs are no more than 30 percent for those who work zero to part-time and no more than 47 percent in the part-time-to-full-time range (Moffitt, 2002). At higher wage levels, however, where the earned income tax credit and other programs are being phased out, cumulative negative income tax rates can be as high as 80 percent. This nonlinear schedule should be expected to encourage individuals to work up to part-time or full-time at their existing, low 
hourly wage rates, but to discourage them from seeking higher wages. ${ }^{5}$

Yet another issue is the extent to which individuals change categories to qualify for certain benefits. The classic issue in this area is whether the restriction of cash welfare to single mothers induces non-marital childbearing and discourages marriage. The evidence suggests that there is some effect of this kind, although the magnitude is quite uncertain (Moffitt, 2003b). There is anecdotal evidence that disabled women with children switch between cash welfare and disability programs to maximize benefits or to avoid work requirements as well. There is essentially no evidence to date, however, on whether single mothers act to avoid work requirements by changing behavior to become exempt.

This increasing categorization of the population springs from the same source as does the preference for work requirements, which is to divide the population into different boxes according to characteristics that are presumed to proxy different types of need, and with a different program for each group. The shift to in-kind transfers can be traced to a public sentiment that if a segment of the population has a certain set of needs, then it should be provided with the goods that address those needs rather than cash. This set of preferences may be the outcome of a voter's utility function which contains not the utility of the poor individual, but rather that individual's consumption of specific goods deemed desirable to the voter

5 Interestingly, this pattern of low marginal tax rates at the bottom and higher marginal tax rates higher up the income distribution--plus presumed low tax rates again at the very top of the income distribution (certainly lower than 80 percent)--fits the textbook optimal tax model of Mirrlees, where a zero marginal tax rate at the top and bottom is optimal under certain conditions Auerbach and Hines (2002) present a recent review of this literature and the assumptions needed for it to go through. 
(Garfinkel, 1973). ${ }^{6}$ Clearly the U.S. voter is revealed by these preferences to be highly paternalistic, preferring that specific groups be judged as deserving and that they consume specific goods viewed as meritorious by the voter.

Conclusion

In its pure form, a Friedman-style negative income tax faces some genuine concerns, including its ambiguous effects on labor supply and the possible gains from work requirements and categorized welfare programs. In the U.S. policy environment, some developments like the earned income tax credit have taken the negative income tax idea farther than the Friedmans envisioned, but other trends like work requirements and the continuing proliferation of welfare programs run fundamentally in opposition to it.

Despite these issues and policy developments, the negative income tax has become the touchstone of economic analysis of welfare programs, in the sense that much of the research in this area is motivated by the negative income tax as an ideal case and is designed to either

${ }^{6}$ A different rationale for in-kind transfers, at least if they are offered in fixed quantity and not in the form of an open-ended price subsidy, is that they may be used to induce only those families who are most needy (that is, have highest marginal utility from benefiting from the good in question) to select themselves into the program. See Nichols and Zeckhauser (1982) and Blackborby and Donaldson (1988) for models of this type, and Heckman (1974) for an empirical illustration in the case of a child-care tied transfer. This argument has not played an important role in policy circles, for while participation rates of eligibles are often less than 100 percent, this has been judged to be partly because of lack of information on eligibility and other barriers to entry. Indeed, in some programs, it appears that the worst-off individuals, who are presumably those who would benefit the most, have the lowest take-up rates. Yet another argument for inkind transfers is that they constrain recipients from taking socially inefficient actions to increase the size of the transfer (Bruce and Waldman, 1991). 
measure its effects or establish alternatives. Moreover, the concept of the negative income tax has played a substantial role in reorienting the thinking of policymakers to the basic message that incentives matter. While this insight does not surprise academic economists, it is a new development in policy circles. In the early 1990s, U.S. policymakers did a 180-degree turn from the implicit assumption that welfare policies had zero behavioral elasticities to designing welfare policies on the explicit assumption that the design of welfare policy had large, nonzero elasticities on labor supply, marriage, education, child-bearing, and other matters of interest to voters. Many of the requirements that have been put in place are not in the spirit of a Friedmanstyle negative income tax, but the focus on incentives is genuinely new. In this sense, Friedman's concept of the negative income tax shows the power of basic economic reasoning to affect policy as well as research. 


\section{References}

Aaron, H. 1973. “Why Is Welfare So Hard to Reform?” Washington: Brookings Institution.

Akerlof, G. 1978. "The Economics of 'Tagging' as Applied to the Optimal Income Tax, Welfare Programs, and Manpower Planning." American Economic Review 68 (March): 8-19.

Alm, J.; Dickert-Conlin, S. and L. Whittington. 1999. "Policy Watch: The Marriage Penalty." Journal of Economic Perspectives 13 (Summer): 193-204.

Atkinson, A.B. 1970. "On the Measurement of Inequality." Journal of Economic Theory 2: 244-263.

Auerbach, A. and J. Hines. 2002. "Taxation and Economic Efficiency." In Handbook of Public Economics, Vol.3, eds. A. Auerbach and M. Friedman. Chicago: University of Chicago Press.

Barth, M. and D. Greenberg. 1971. "Incentive Effects of Some Pure and Mixed Transfer Systems." Journal of Human Resources 6 (Spring): 149-170.

Besley, T. and S. Coate. 1992. "Workfare Versus Welfare: Incentive Arguments for Work Requirements in Poverty-Alleviation Programs." American Economic Review 82 (March): 249-26.

Blackorby, C. and D. Donaldson. 1988. "Cash Versus Kind, Self-Selection, and Efficient Transfers." American Economic Review 78 (September): 691-700.

Brown, C. and W. Oates. 1987. "Assistance to the Poor in a Federal System." Journal of Public Economics 32: 307-330.

Browning, E. 1975. Redistribution and the Welfare System. Washington: American Enterprise Institute.

Bruce, N. and M. Waldman. 1991. "Transfers In Kind: Why They Can Be Efficient and Nonpaternalistic.” American Economic Review 81 (December): 1345-1351.

Brueckner, J. 2000. "Welfare Reform and the Race to the Bottom: Theory and Evidence." Southern Economic Journal 66 (January): 505-525.

Burke, V. 2001. Cash and Noncash Benefits for Persons with Limited Income: Eligibility Rules, Recipient and Expenditure Data, FY1998-FY2000. Washington: Congressional Research Service.

Cuff, K. 2000. "Optimality of Workfare with Heterogeneous Preferences." Canadian Journal of 
Economics 33 (February): 149-174.

Diller, M. 2000. "The Revolution in Welfare Administration: Rules, Discretion, and Entrepreneurial Government.” NYU Law Review 75 (November): 1121-1220.

Fortin, B., M. Truchon; and L. Beausejour. 1993. "On Reforming the Welfare System: Workfare Meets the Negative Income Tax." Journal of Public Economics 51 (1993): 119-151.

Friedman, M. 1962. Capitalism and Freedom. Chicago: University of Chicago Press. . 1969. Testimony on the Family Assistance Plan. In U.S. Congress, House of Representatives, Committee on Ways and Means, $\underline{\text { Social Security and Welfare Proposals, }}$ Hearings, $91^{\text {st }}$ Congress, $1^{\text {st }}$ Session, November 7, Part 6, pp. 1944-1958.

Friedman, M. and R. Friedman. 1980. Free to Choose. New York: Harcourt Brace Jovanovich. Gallagher, L. Jerome; Megan Gallagher; Kevin Perese; Susan Schreiber; and Keith Watson. 1998. "One Year After Federal Welfare Reform: A Description of State Temporary Assistance for Needy Families (TANF) Decisions as of October 1997." Washington: The Urban Institute.

Garfinkel, I. 1973. "Is In-Kind Redistribution Efficient." Quarterly Journal of Economics 87 (May): 320-330.

Garrett, B. and J. Holahan. 2000. "Welfare Leavers, Medicaid Coverage, and Private Health Insurance. ANF Paper B-13. Washington: Urban Institute.

Gruber, J. 2003. "Medicaid." In Means-Tested Transfer Programs in the United States, ed. R. Moffitt. Chicago: University of Chicago Press.

Heckman, J. 1974. "Effects of Child-Care Programs on Women's Work Effort." Journal of Political Economy 82 (March-April, Part 2): S136-S163.

Hotz, V. J. and K. Scholz. 2003. "The Earned Income Tax Credit." In Means-Tested Transfer Programs in the United States, ed. R. Moffitt. Chicago: University of Chicago Press.

Lampman, R. 1965. "Approaches to the Reduction of Poverty." American Economic Review 55 (May): 521-529.

Lampman, R. 1968. "Expanding the American System of Transfers to Do More for the Poor." U.S. Congress Senate Committee Hearings, Joint Economic Committee, $90^{\text {th }}$ Congress, Vol. 1915. Washington: Government Printing Office.

Lurie, I., ed. 1975. Integrating Income Maintenance Programs. NY: Academic Press. 
Institution.

2001. "Changing Welfare Offices." Policy Brief No. 9. Washington: Brookings

Mirrlees, J. 1971. "An Exploration in the Theory of Optimum Income Taxation.” Review of Economic Studies 38 (April): 175-208.

Moffitt, R. 1992. "Incentive Effects of the U.S. Welfare System: A Review." Journal of Economic Literature 30 (March): 1-61.

. 2002. "Welfare Programs and Labor Supply." In Handbook of Public Economics,

Vol.4, eds. A. Auerbach and M. Friedman. Chicago: University of Chicago Press.

. 2003a. "Introduction." In Means-Tested Transfer Programs in the United States, ed.

R. Moffitt. Chicago: University of Chicago Press.

. 2003b. "The Temporary Assistance for Needy Families Program." In Means-Tested Transfer Programs in the United States, ed. R. Moffitt. Chicago: University of Chicago Press.

Moynihan, D. 1973. The Politics of a Guaranteed Annual Income: The Nixon Administration and the Family Assistance Plan. New York: Random House.

Nichols, A. and R. Zeckhauser. 1982. "Targeting Transfers Through Restrictions on Recipients.” American Economic Review 72 (May): 372-377.

Parsons, D. 1996. "Imperfect 'Tagging' in Social Insurance Programs." Journal of Public Economics 62 (October): 183-208.

Pauly, M. 1973. "Income Redistribution as a Local Public Good." Journal of Public Economics 2 (February): 35-58.

SRI International, Inc. 1983. "Final Report of the Seattle/Denver Income Maintenance Experiment: Volume I.” Menlo Park, California.

Tobin, J. 1966. “On the Economic Status of the Negro.” Daedalus (Fall): 89-895.

Tobin, J.; J. Pechman; and P. Mieszkowski. 1967. “Is a Negative Income Tax Practical?” Yale Law Journal 77 (November): 1-27.

Wheaton, W. 2000. "Decentralized Welfare: Will There Be Underprovision?" Journal of Urban Economics 48 (November): 536-555.

Zedlewski, S. and S. Brauner. 1999. "Declines in Food Stamp and Welfare Participation: Is There a Connection?" WP 99-13. Washington: Urban Institute. 
Table 1

Effect of Negative Income Tax Plans with Different Levels of G and t on Weekly Hours of Work of Single Mothers

\begin{tabular}{|c|c|c|c|c|}
\hline & \multicolumn{4}{|c|}{ Negative Income Tax Rate } \\
\hline & 1.00 & 0.75 & 0.50 & 0.25 \\
\hline \multicolumn{5}{|c|}{ Low elasticities } \\
\hline $\mathrm{G}=.50$ & -0.81 & -0.49 & -0.35 & -0.33 \\
\hline $\mathrm{G}=.75$ & -2.18 & -1.08 & -0.68 & -0.55 \\
\hline $\mathrm{G}=1.00$ & -4.02 & -1.74 & -1.00 & -0.64 \\
\hline \multicolumn{5}{|c|}{ High elasticities } \\
\hline $\mathrm{G}=.50$ & -2.06 & -2.22 & -2.02 & -2.26 \\
\hline $\mathrm{G}=.75$ & -4.62 & -4.99 & -4.29 & -3.87 \\
\hline $\mathrm{G}=1.00$ & -7.34 & -7.92 & -6.50 & -5.31 \\
\hline
\end{tabular}

Notes:

$\mathrm{G}=$ Guarantee as a percentage of the official government poverty line

The substitution and income elasticities are .05 and -.02, respectively, in the 'low' case and are .20 and -.25 in the 'high' case.

Source: Moffitt (1992, Table 5) 
Table 2

Composition of Real Expenditures on Means-Tested Transfers, 1968-2000 (billions of FY2000 dollars)

\begin{tabular}{|c|c|c|c|c|c|c|c|c|}
\hline & Medical & Cash & Food & Housing & Education & $\begin{array}{c}\text { Jobs/ } \\
\text { Training }\end{array}$ & Services & Energy \\
\hline 1968 & $\begin{array}{l}24.1 \\
(30)\end{array}$ & $\begin{array}{l}37.8 \\
(47)\end{array}$ & $\begin{array}{l}4.5 \\
(6)\end{array}$ & $\begin{array}{l}3.9 \\
(5)\end{array}$ & $\begin{array}{l}4.3 \\
(5)\end{array}$ & $\begin{array}{l}3.8 \\
(5)\end{array}$ & $\begin{array}{l}2.5 \\
(3)\end{array}$ & $\begin{array}{c}0 \\
(0)\end{array}$ \\
\hline 1978 & $\begin{array}{l}65.1 \\
(29)\end{array}$ & $\begin{array}{l}65.4 \\
(29)\end{array}$ & $\begin{array}{l}25.1 \\
(11)\end{array}$ & $\begin{array}{c}20.7 \\
(9)\end{array}$ & $\begin{array}{c}11.5 \\
(5)\end{array}$ & $\begin{array}{l}26.1 \\
(12)\end{array}$ & $\begin{array}{c}11.4 \\
(5)\end{array}$ & $\begin{array}{l}.7 \\
(0)\end{array}$ \\
\hline 1988 & $\begin{array}{l}96.0 \\
(38)\end{array}$ & $\begin{array}{l}66.7 \\
(26)\end{array}$ & $\begin{array}{l}31.2 \\
(12)\end{array}$ & $\begin{array}{c}23.2 \\
(9)\end{array}$ & $\begin{array}{c}17.1 \\
(7)\end{array}$ & $\begin{array}{l}5.6 \\
(2)\end{array}$ & $\begin{array}{l}9.6 \\
(4)\end{array}$ & $\begin{array}{l}2.9 \\
(1)\end{array}$ \\
\hline 1995 & $\begin{array}{c}196.9 \\
(47)\end{array}$ & $\begin{array}{c}103.3 \\
(25)\end{array}$ & $\begin{array}{l}43.6 \\
(10)\end{array}$ & $\begin{array}{c}35.8 \\
(9)\end{array}$ & $\begin{array}{c}18.1 \\
(4)\end{array}$ & $\begin{array}{l}6.1 \\
(1)\end{array}$ & $\begin{array}{c}12.8 \\
(3)\end{array}$ & $\begin{array}{l}1.9 \\
(0)\end{array}$ \\
\hline 2000 & $\begin{array}{c}225.9 \\
(52)\end{array}$ & $\begin{array}{l}91.7 \\
(21)\end{array}$ & $\begin{array}{c}34.3 \\
(8)\end{array}$ & $\begin{array}{c}34.9 \\
(8)\end{array}$ & $\begin{array}{c}20.4 \\
(5)\end{array}$ & $\begin{array}{l}7.3 \\
(2)\end{array}$ & $\begin{array}{c}20.7 \\
(5)\end{array}$ & $\begin{array}{l}1.7 \\
(0)\end{array}$ \\
\hline
\end{tabular}

Notes:

Combined federal and state and local.spending for the largest 84 means-tested transfer programs; each category includes all programs of that type. The ten largest programs in 2000 are Medicaid and Veterans Medical Care (Medical); the Earned Income Tax Credit, Supplemental Security Income, Temporary Assistance for Needy Families, and Foster Care (Cash); Food Stamps (Food); Section 8 Housing Benefits (Housing); Pell Grants (Education), and the Child Care Development Block Grant (Services).

Row percents shown in parentheses; may not add to 100 because of rounding Source: Burke (2001), Moffitt (2003a) 


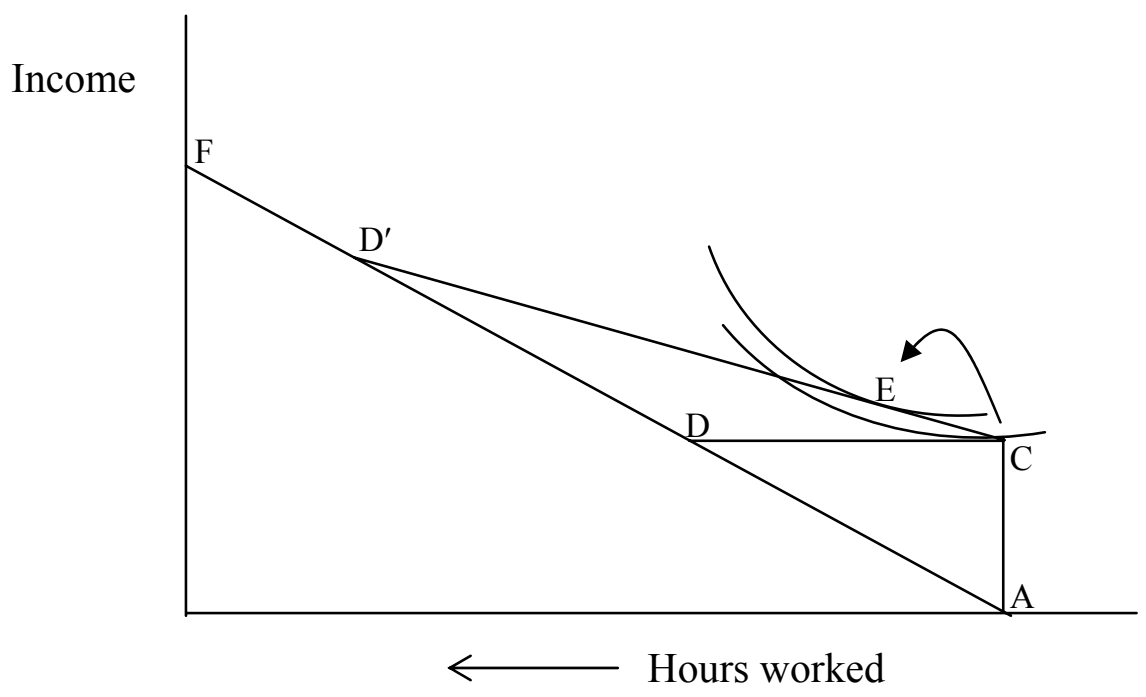

Figure 1. Negative Income Tax 


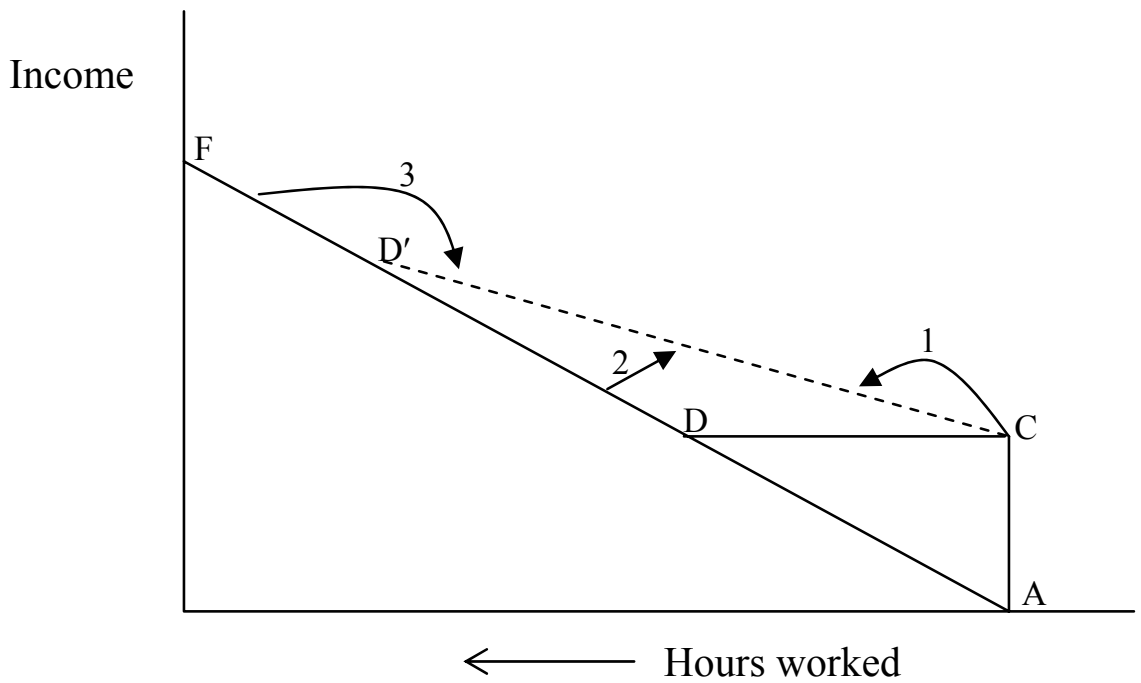

Figure 2. Effect of a Negative Income Tax on Labor Supply 


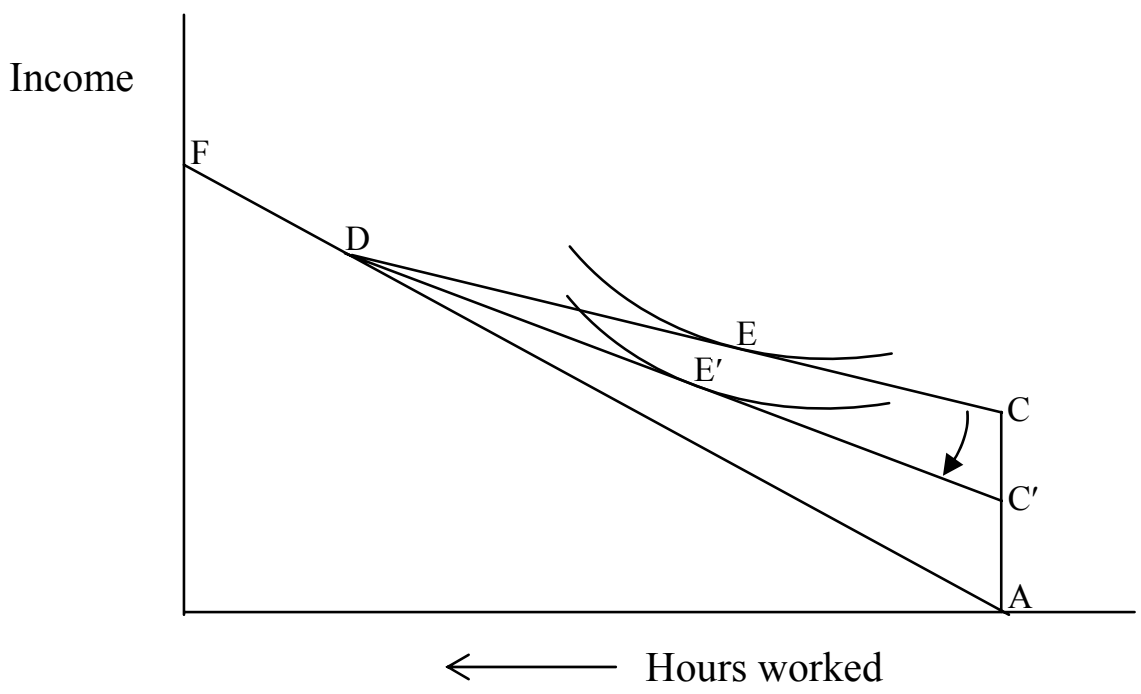

Figure 3. Reducing G and t Simultaneously 


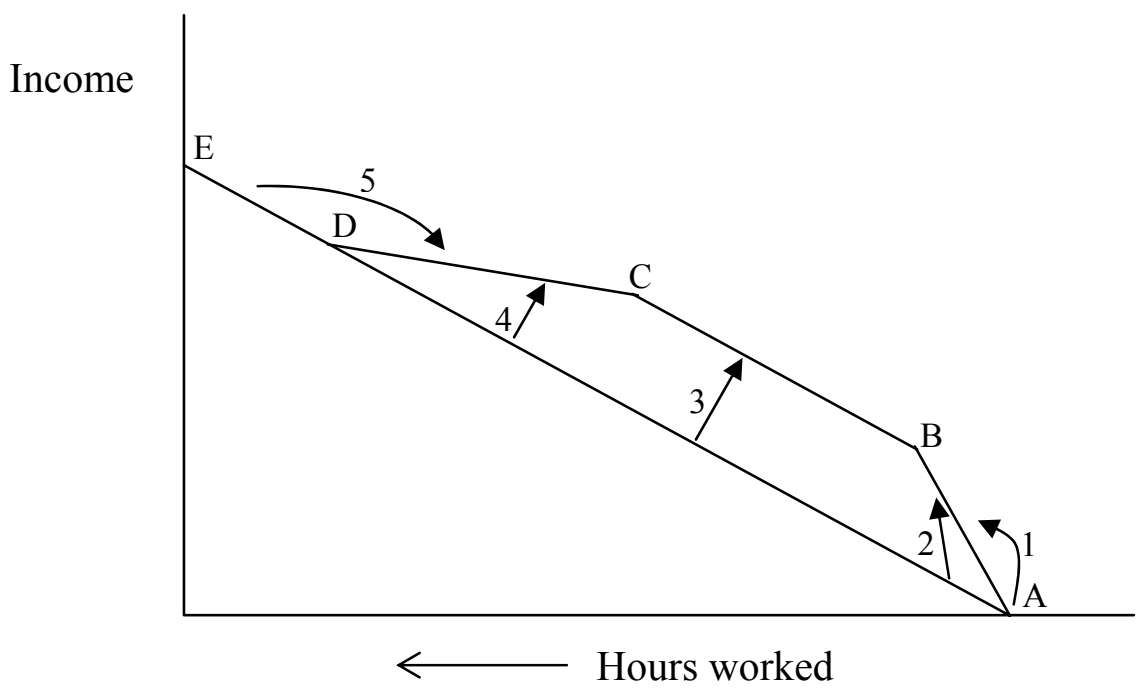

Figure 4. Earned Income Tax Credit 


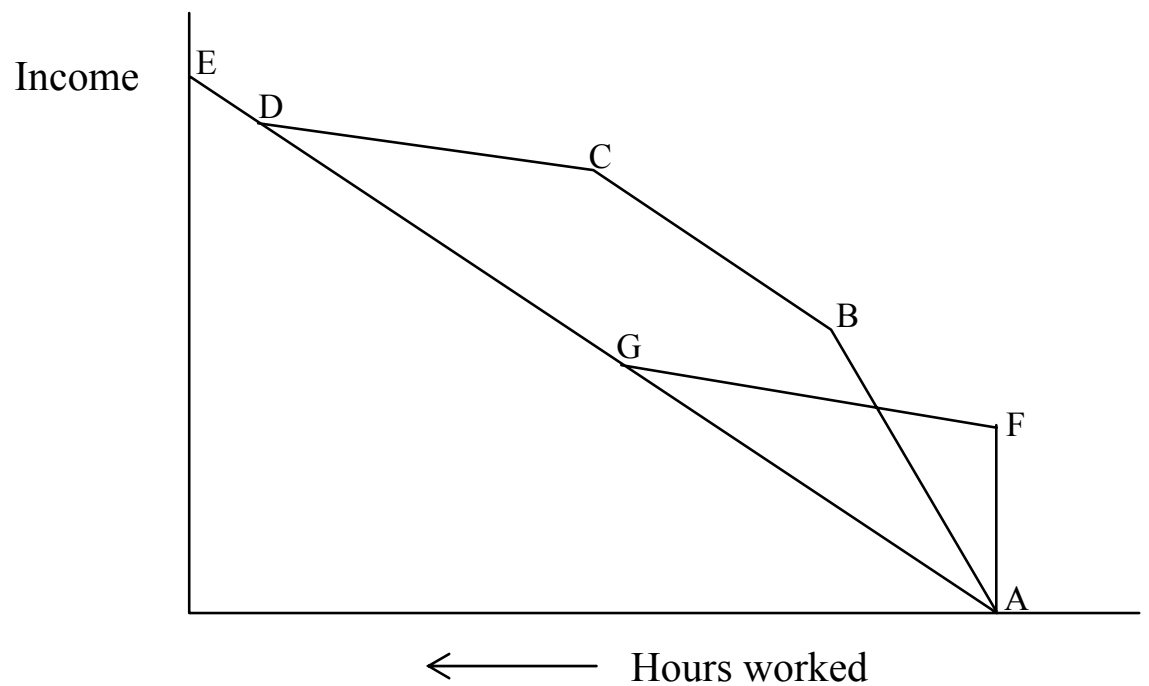

Figure 5. Earned Income Tax Credit Plus Negative Income Tax 